\title{
MENDIDIK ANAK MENJADI MANUSIA YANG BERKARAKTER
}

\author{
Sudaryanti \\ sudaryanti@uny.ac.id \\ PAUD Universitas Negeri Yogyakarta
}

\begin{abstract}
Abstrak
Karakter anak tidak terlepas dari bagaimana pendidikan dan pola asuh orangtua dirumah. Karakter anak dibentuk dari apa yang dipelajarinya dirumah dalam keluarga, disekolah, dan di masyarakat. Anak yang berasal dari keluarga yang baik berpotensi rusak karakternya jika lingkungan sekolah kacau dan lingkungan bergaul salah, begitu juga dengan kondisi di masyarakat yang tidak saling mendukung (bersinergi) dalam penyemaian karakter anak. Untuk mengoptimalkan penanaman nilai-nilai karakter pada anak dibutuhkan adanya pembiasaan dari orang-orang disekitar anak. Nilai-nilai karakter yang ditanamkan dapat merujuk nilai karakter dikembangkan Lickona dan sistem among yang dikembangkan Ki Hajar Dewantara. Menurut Lickona, pendidikan karakter ditanamkan melalui kebiasaan (habituation) tentang hal yang baik sehingga peserta didik menjadi paham (domain kognitif) nilai yang baik dan biasa melakukannya (domain perilaku). Sedangkan menurut Ki Hajar Dewantara sistem among merupakan metode pembelajaran dan pendidikan yang berdasarkan pada asih,asah,dan asuh(care and dedivcation based on love). Dengan memadukan pembiasaan berbagai nilai-nilai karakter positif yang ada, diharapkan penanaman nilai karakter pada anak akan lebih optimal.
\end{abstract}

Kata kunci: Nilai-nilai Karakter, anak usia dini

\begin{abstract}
Children's character is always related to parenting and education received at home. It is developed from what they learn from their family, schools, and society. Children from a good family have the risks of corrupted characters if they are within a discouraging school environment and community. Counted in that matter is also the discouraging and unsupportive society that is unable to make a synergy in developing children's characters. To optimize the character development to the students, it needs custom and habituation from the surrounding people. The developed characters can refer to the character values developed by Lickona and the among system (nurture) developed by Ki Hajar Dewantara. According to Lickona, character education is gained through habituation on good things thus students understand it (cognitive domain) and are accustomed to do it (behavior domain). While according to Ki Hajar Dewantara, among system (nurture) is a learning method and education based on the principles of asih, asah, and asuh (care and dedication based on love). Combining the habituation of certain positive character values, it is hoped that the development of character values to the children will be more optimal.
\end{abstract}

Keywords: character values, early childhood 


\section{Pendahuluan}

Anak-anak adalah buah hati belahan jantung orang tua. Masa depannya berarti masa depan orang tua juga. Kebahagiannya berarti kebahagiaan orang tua juga. Tidak ada orang tua yang tega membiarkan anaknya tak berkarakter dan gagal dalam hidupnya. Sebagai orang tua kita punya tanggung jawab membantu anak-anak belajar memahami masa depannya dari lahir sampai dewasa ,bahkan sampai kita meninggal dunia. Inilah letak amanah Tuhan yang dilimpahkan kepundak kita.

Karakter anak tidak terlepas dari bagaimana pendidikan dan pola asuh orangtua dirumah. Karakter anak dibentuk dari apa yang dipelajarinya dirumah dalam keluarga, disekolah, dan di masyarakat. Ketiga lingkungan tersebut merupakan sistem. Seorang anak tidak akan memiliki karakter yang baik apabila salah satu dari ketiga lingkungan tersebut bermasalah. Sekolah yang kondusif dalam penyemaian pendidikan karakter tidak akan efektif membentuk karakter anak jika situasi dirumah tidak kondusif dan terjadi kekosongan /krisis moral dimasyarakat. Anak yang bersal dari keluarga yang baik berpotensi rusak karakternya jika lingkungan sekolah kacau dan lingkungan bergaul salah, begitu juga dengan kondisi di masyarakat yang tidak saling mendukung (bersinergi) dalam penyemaian karakter anak. Oleh karena itu, pembudayaan dan pemberdayaan menjadi hal yang sangat penting untuk dilaksanakan secara bersama. Proses pembudayaan yang dilakukan oleh pihak luar, terhadap anak sesungguhnya sebuah intervensi. Intervensi atau campur tangan mutlak diperlukan untuk menghindari kesalahan tafsir dan dalam rangka mempermudah dan mempercepat pendidikan karakter. Satuan pendidikan melakukan intervensi sesuai dengan visi, misi dan nilai yang dianut. Keluarga juga melakukan intervensi sesuai dengan nilai dan harapan yang dianut oleh keluarga. Intervensi masyarakat berdasarkan kultur, nilai dan norma yang dianut dan berlaku dimasyarakat, juga budaya yang menjadi tradisi di masyarakat.

Pembudayaan dan pemberdayaan akan efektif jika diikuti dengan proses pembiasaan (habituasi). Pembiasaan berpedoman pada kebijakan yang diambil, adanya standar baku yang berbentuk pedoman ,yang disesuaikan dengan kondisi lingkungan, serta sumber daya yang dimilikinya. Pembiasaan tidak berada diruang hampa, tetapi di dalam spektrum lingkungan sekolah, keluarga, dan masyarakat, sehingga kontektualisasi merupakan sebuah keharusan. Transfer nilai-nilai luhur dalam diri anak melalui keluarga, sekolah, dan masyarakat hasil yang diharapkan adalah terwujudnya perilaku berkarakter yang tidak menyimpang dari nilai-nilai yang ada didalam dasar Negara kita yaitu Pancasila. Dengan kata lain, perilaku yang berkarakter menjadi budaya yang melekat pada diri anak. Anak atau individu yang berbudaya adalah individu yang mampu mengajari dirinya sendiri.

\section{Pola asuh yang mendidik}

Ada tiga pola asuh orang tua terhadap anak yaitu: Authoritatan, Permisif dan Authoritave. Dorothy Law Nolte ( dalam Putri Pandan Wangai: 34-35), menyatakan bahwa anak belajar dari kehidupan lingkungannya. Sebagai contoh jika anak dibesarkan dengan celaan, maka ia belajar memaki. Jika anak dibesarkan dengan permusuhan, ia akan belajar berkelahi. Jika anak dibesarkan dengan cemoohan, ia belajar rendah diri. Jika anak dibesarkan dengan penghinaan, ia belajar menyesali diri. Jika anak dibesarkan dengan toleransi, ia belajar menahan diri. Jika anak dibesarkan dengan pujian, ia belajar menghargai. Jika anak dibesarkan dengan sebaik-baik perlakuan, ia akan belajar keadilan. Jika anak dibesarkan dengan rasa aman, ia belajar menaruh kepercayaan. Jika anak dibesarkan dengan dukungan ia belajar menyenangi diri. Jika anak dibesarkan dengan kasih sayang dan 
persahabatan, ia belajar menemukan cinta dalam kehidupan. Dari beberapa contoh yang dikemukakakan Dorothy tersebut menunjukkan bahwa lingkungan, terutama keluarga akan membentuk sikap dan perilaku anak. Setiap orang tua menghendaki dan mempunyai ambisii bahwa anaknya "sukses" dimasa depannya. Sukses dalam hal ini bukan pada karier, akan tetapi lebih pada aspek kognitif, afektif, serta perilaku. Salah satu cara agar anak 'sukses" dimasa depannya yang perlu dilakukan dalam lingkungan keluarga, yaitu dengan menerapkan pola asuh orang tua terhadap anak yang tepat. Kesalahan yang terjadi dapat berakibat buruk bagi masa depan anak, baik dari segi kognitif, afektif maupun perilaku. Akan kita jelaskan ketiga pola asuh orang tua tersebut yaitu:

\section{Authotarian (otoriter)}

Pola asuh tipe ini menggunakan pendekatan yang memaksakan kehendak orang tua kepada anak. Anak harus menurut orang tua. Kemauan orang tua harus dituruti, anak tidak boleh mengeluarkan pendapat. Pola asuh ini dapat mengakibatkan anak menjadi penakut, pencemas, menarik diri dari pergaulan, kurang adaptasi, kurang tujuan, mudah curiga kepada orang lain dan mudah stress.

\section{Permisif}

Pola asuh tipe ini orang tua serba membolehkan anak berbuat apa saja. Orang tua memiliki kehangatan dan menerima apa adanya. Kehangatan, cenderung memanjakan, dituruti keinginanya. Sedangkan menerima apa adanya akan cenderung memberikan kebebasan kepada anak untuk berbuat apa saja. Pola asuh ini dapat mengakibatkan anak agresif, tidak patuh pada orang tua, sok kuasa, kurang mampu mengontrol diri, dan kurang intens mengikuti pelajaran sekolah.

\section{Authoritative}

Orang tua sangat memperhatikan kebutuhan anak dan mencukupinya dengan pertimbangan faktor kepentingan dan kebutuhan. Pola asuh ini dapat mengakibatkan anak mandiri, mempunyai control diri, dan kepercayaan diri yang kuat, dapat berinteraksi dengan teman sebayanya dengan baik, mampu menghadapi stress,mempunyai minat terhadap hal-hal yang baru, kooperatif dengan orang dewasa, penurut, patuh dan berorientasi pada prestasi. Pola asuh orang tua mempengaruhi perilaku anak. Sekarang tinggal memilih tipe pola asuh yang bagaimana yang akan kita terapkan kepada anak kita menjadi manusia yang berkarakter.

Orang tua sangat berperan dalam mendidik anak baik secara langsung maupun tidak langsung sifat dan karakter anak-anaknya, dampaknya bisa positif dan bisa juga negatif. Mendidik anak sejak anak usia dini secara langsung, tentu saja dilakukan secara sengaja dengan mengajarkan hal-hal yang positif dan bermanfaat kepada anak. Sedangkan yang tidak langsung, sesuai dengan sifat anak yang suka meniru, anak-anak selalu melakukan apa yang orang tua lakukan. Uniknya, tidak sedikit orang tua menyadari hal ini, atau setidaknya sedikit lengah bahwa perilaku mereka sangat berdampak kepada tingkah laku anak.

Peran dan tugas guru dalam membentuk karakter anak semakin berat. Dalam era globalisasi telah melahirkan sejunlah tantangan yang tidak bisa dianggab remeh dan disepelekan, hal ini harus disikapi secara profesional.menurut Kunandar (Barnawi \&M.Arifin:98) ada lima tantangan globalisasi yang harus disikapii guru dengan mengedepankan profesionalisme antara lain: 1)perkembangan IPTEK yang begitu cepat dan mendasar; 2)krisis moral yang melanda bangsa dan Negara Indonesia; 3)krisis social seperti kriminalitas, kekerasan, pengangguran, dan kemiskinan yang terjadi dimasyarakat; 4)krisis identitas sebagai bangsa dan Negara Indonesia; 5)adanya perdagangan bebas,baik tingkat ASEAN, Asia Pasifik, maupun dunia. 
Secara langsung dan tidak langsung, kelima tantangan itu membutuhkan penyelesaian melalui peran guru dalam mendidik anak menjadi manusia yang berkarakter. Krisis moral, krisis social, dan krisis identitas menunjukkan pola warga bangsa yang sedang kehausan akan asupan nilai-nilai kehidupan. Perkembangan IPTEK dan perdagangan bebas merupakan sebuah tantangan besar yang hanya bisa dihadapi oleh manusia yang memiliki karakter ilmiah dan mampu bersaing dalam hidupnya. Oleh karena itu, peran guru akan sangat menentukan dalam mendidik dan melahirkan manusia-manusia yang mampu menghadapi tantangan dimasa global ini.

Lickona,Schaps, dan Lewis serta Azra (dalam Suyanto,2010) menguraikan beberapa pemikiran mengenai peran guru, diantaranya adalah sebagai berikut:

1. Pendidik perlu terlibat dalam proses pembelajaran ,diskusi,dan mengambil inisiatif sebagai upaya membangun pendidikan karakter.

2. Pendidik bertanggung jawab menjadi model yang memiliki nilai-nilai moral dan memanfaatkan kesempatan untuk mempengaruhi siswasiswanya.Artinya ,guru dilingkungan sekolah hendaknya mampu menjadi "uswah hasanah"yang hidup bagi setiap peserta didik.Mereka juga harus terbuka dan siap untuk mendiskusikan dengan peserta didik tentang berbagai nilai-nilai yang baik tersebut.

3. Pendidik perlu memberikan pemahaman bahwa karakter siswa tumbuh melalui kerja sama dan berpartisipasi dalam mengambil keputusan.

4. Pendidik perlu melakukan refleksi atas masalah moral berupa pertanyaanpertanyaan rutin untuk memastikan bahwa siswa-siswanya mengalami perkembangan karakter.

5. Pendidik perlu menjelaskan atau mengklarifikasikan kepada peserta didik secara terus- menerus tentang berbagai nilai yang baik dan yang buruk.

Kilpatrick (1992) dan Lickona(1992) merupakan dua tokoh pencetus utama pendidikan karakter (dalam Darmiyati Zuchdi:10) yang mempercayai adanya keberadaan moral absolute, yakni bahwa moral absolute perlu diajarkan kepada generasi muda agar mereka paham betul mana yang baik dan benar. Oleh karena itu ,pendidikan karakter mempunyai makna lebih tinggi dari pada pendidikan moral,karena bukan sekedar mengajarkan mana yang benar dan mana yang salah,lebih dari itu, pendidikan karakter menanamkan kebiasaan (habituation) tentang hal yang baik sehingga peserta didik menjadi paham (domain kognitif) nilai yang baik dan biasa melakukannya (domain perilaku).

\section{Pendidikan karakter}

Pendidikan karakter merupakan pendidikan ihwal karakter, atau pendidikan yang mengajarkan hakekat karakter dalam ketiga ranah yaitu cipta, rasa dan karsa. Makna pendidikan karakter merupakan pendidikan yang mendukung pekembangan social, emosional, dan etis siswa (http://www.character.orgl),pendidikan

karakter adalah "character education is an educational movement that support the social,emotional and ethical development of students. Melihat definisi tersebut pendidikan karakter pada prinsipnya adalah upaya untuk menumbuhkan kepekaan dan tanggung jawab social, membangun kecerdasan emosional, dan mewujudkan siwa yang memiliki etika tinggi. Sejak kecil tanpa kita sadari, orang tua kita telah melaksanakan /mengajari hal-hal yang baik yang menyangkut pendidikan sosial, emosional, dan etika. Sebagai contoh mengajari dan melatih anaknya yang masih kecil untuk berbagi ketika makan atau bermain, orang tua telah menanamkan pendidikan karakter sejak masih usia dini. Ketika anaknya bangun jatuh dukungan dan pujian yang dilontarkan orang tua merupakan penguatan karakter anak. Anak 
dilatih untuk untuk kekamar kecil ketika mau buang air juga merupakan pendidikan karakter yang berkaitan dengan etika. Masih pada situs yang sama dikatakan pendidikan karakter mengajarkan siswa bagaimana menjadi diri mereka terbaik dan bagaimana mereka melakukan pekerjaan terbaik serta memfasilitasi budaya sekolah yang positif dan transformasi iklim sekolah yang kondosif."Charckter education teaches student haw to be their best selves and haw to do their best work while also facilitating positive school culture and climate transformation"

Dalam

situs

http://www.en.wikipedia.org../wiki/charact

$\underline{\text { er }}$-education dinyatakan, "Character

education is an umbrella term loosely used to describe the teaching of children in a manner that will help them develop variously as moral, civic, good,mannered, behaved, non-bullying, healthy , critical, successful, traditional, compliant and or socially acceptable beings"'(pendidikan karakter merupakan terminology yang mendeskripsikan suatu bentuk pembelajaran kepada anak-anak makna dan pengembangan atas moral, hokum, baik, santun, berperilaku, non-bullying ,sehat, kritis, skses, menghargai tradisi, dan kesadaran diri sebagai makhluk social).

$$
\text { Megawangi (dalam Dharma }
$$

Kesuma,2001) mendefinisikan pendidikan karakter sebagai sebuah usaha untuk mendidik anak-anak agar dapat mengambil keputusan dengan bijak dan mempraktikkannya dalam kehidupan sehari-hari sehingga mereka dapat memberikan konstribusi yang positif kepada lingkungannya.

Dalam

www.slideshare.net/gusipung/ pendidikan karakter, Syaiful Anam mendefinisikan pendidikan karakter sebagai proses internalisasi budaya kedalam diri seseorang dan masyarakat sehingga membuat orang dan masyarakat beradab. Pendidikan bukan hanya transfer ilmu pengetahuan saja, melainkan sebagai sarana pembudayaan dan penyaluran nilai.
Pendidikan yang diberikan kepada anak harus menyentuh dimensi dasar kemanusiaan yaitu: 1) afektif yaitu yang tercermin padaa kualitas keimanan, ketakwaan, akhlak mulia, termasuk budipekerti luhur, serta kepribadian unggul, dan kompetensi estetis; 2) kognitif yang tercermin pada kapasitas piker dan daya intelektualitas untuk menggali dan mengembangkan serta menguasai ilmu pengetahuan dan teknologi; 3)psikomotorik, yang tercermin pada kemampuan mengembangkan keterampilan teknis, kecakapan praktis, dan kompetensi kinestetik.

Dirjen Dikti dalam www.kopertis 8.org/.../pendidikan $\% 20 \quad$ karakter menyatakan' Pendidikan karakter dapat dimaknai sebagai pendidikan nilai, pendidikan budi pekerti, pendidikan moral, pendidikan watak, yang bertujuan mengembangkan kemampuan peserta didik untuk memberikan keputusan baik -buruk, memelihara apa yang baik, mewujudkan, dan menebar kebaikan itu dalam kehidupan sehari-hari dengan sepenuh hati.”.

Pandangan Ki Hajar Dewantara mengenaii pendidikan dan kebudayaan .

Pemikiran Ki Hajar Dewantara, melihat bahwa manusia lebih pada sistemi kehidupan psikologisnya. Menurut beliau manusia memiliki daya jiwa yaitu cipta, rasa, dan karsa. Pengembangan manusia seutuhnya menuntut pengembangan semua daya secara seimbang. Pengembangan yang terlalu menitik beratkan pada satu daya saja akan menghasilkan ketidakbutuhan perkembangan sebagai manusia. Beliau mengatakan bahwa pendidikan yang menekankan pada aspek intelektual belaka hanya akan menjauhkan peserta didik dari masyarakatnya.

Kenyataan bahwa pendidikan sampai sekarang ini hanya menekankan pada pengembangan daya cipta, dan kurang memperhatikan pengembangan olah rasa dan karsa. Andai saja kita tidak sadari akan berakibat menjadikan manusia kurang humanis atau tidak manusiawi. Ki Hajar Dewantara juga memandang pendidikan 
dari sisi sosioantropologis, kekhasan manusia yang membedakannya dengan makhluk lain adalah bahwa manusia itu berbudaya, sedang makhluk lain tidak berbudaya. Salah satu cara yang efektif untuk menjadikan manusia lebih manusiawi adalah dengan mengembangkan kebudayaannya. Persoalannya budaya dalam masyarakat itu berbeda-beda. Masalah kebudayaan berlaku pepatah: "lain ladang lain belalang,lain lubuk lain ikannya"." Manusia akan benarbenar menjadi manusia kalau ia hidup dalam kebudayaanya sendiri". Manusia yang seutuhnya antara lain dimengerti sebagai manusia itu sendiri ditambah dengan budaya masyarakat yang melingkupinya. Beliau mengubah namanya karena ingin menunjukkan sikapnya dalam melaksanakan pendidikan yaitu dari satria pinandita menjadi panindita satria artinya dari pahlawan yang berwatak guru spiritual ke guru spiritual yang berjiwa ksatria ,yang mempersiapkan diri dan peserta didik untuk melindungi bangsa dan negara.

Dengan nama Ki Hajar Dewantara, ia dapat merakyat dan demokratis. Bagi Ki Hajar Dewantara, para guru hendaknya menjadi pribadi yang bermutu dalam kepribadiannya dan kerohanian, baru kemudian menyediakan diri untuk menjadi pribadi pahlawan dan juga menyiapkan para peserta didik untuk menjadi pembela nusa dan bangsa. Dengan kata lain, yang diutamakan sebagai pendidik pertamatama adalah fungsinya sebagai model atau figur keteladanan, baru kemudian sebagai fasilitator atau pengajar. Oleh karena itu, nama Ki Hajar Dewantara sendiri memiliki makna sebagai guru yang membelajarkan kebaikan, keluhuran, keutamaan. Pendidik atau sang hajar adalah seseorang yang memiliki kelebihan dibidang agama dan keimanan, sekaligus masalah-masalah sosial kemasyarakatan. Modelnya adalah kyai Semar (menjadi perantara antara Tuhan dan manusia, mewujud kehendak Tuhan didunia ini). Sebagai pendidik yang merupakan perantara Tuhan maka guru sejati sebenarnya berwatak pendita juga, yaitu mampu menyampaikan kehendak Tuhan dan membawa keselamatan .

Secara garis besar, Ki Hajar Dewantara mengemukakan pendidikan sebagai daya upaya untuk memajukan budi pekerti, pikiran, dan fisik seseorang. Ketiga elemen ini, menurutnya, tidak dapat dipisahkan untuk mencapai kesempurnaan hidup. Dalam kaitan dengan pendidikan nasional, daya upaya memajukan ketiga elemen ini hendaknya berdasarkan garis hidup bangsanya atau berdasarkan kebudayaan bangsanya dan ditujukan untuk meningkkatkan derajat serta kemerdekaan manusia sebagai anggota sebuah persatuan (bangsa). Kemerdekaan yang dimaksud disini adalah berdiri sendiri ,tidak bergantung kepada orang lain, dan dapat mengatur dirinya sendiri. Lebih jauh, dalam hidup merdeka tersebut, Ki Hajar Dewantara menekankan pentingnya harmoni yaitu suatu keadaan pesatuan yang selaras. Untuk mencapai ini masing-masing anggota persatuan harus ingat bahwa ia hidup bersama-sama dengan orang lain yang juga berhak menuntut kemerdekaannya. Oleh karena itu, golongan yang berbeda harus mengatasi perbedaan tersebut dan mementingkan peri kehidupan bersama.

Manusia merdeka adalah tujuan taman siswa. Merdeka baik fisik, mental, dan kerohanian. Namun, kemerdekaan pribadi dibatasi oleh tertib damainya kehidupan bersama dan ini mendukung sikap seperti keselarasan, kekeluargaan, musyawarah, toleransi, kebersamaan, demokrasi, tanggung jawab, dan disiplin. Sedangkan maksud pendirian Taman Siswa adalah membangun budayanya sendiri, jalan hidup sendiri dengan mengembangkan rasa kemerdekaan dalam hati setiap orang melalui media pendidikan yang berlandaskan pada aspek-aspek nasional.

Landasan filosofisnya adalah nasionalistis dan universalistis. Nasionalistis maksudnya budaya nasional, bangsa merdeka, dan independen baik secara politis, ekonomis, maupun spiritual. 
Universal dalam arti berdasarkan kepada hukum alam (natural law) segala sesuatu merupakan perwujudan dari kehendak Tuhan. Prinsip dasarnya adalah kemerdekaan, merdeka dari segala hambatan cinta, kebahagiaan, keadilan, dan kedamaian tumbuh dalam diri (hati) manusia. Situasi yang dibutuhkan dalam dunia pendidikan adalah situasi yang berprinsip pada kekeluargaan, kebaikan hati, empati, cinta kasih, dan penghargaan terhadap masing-masing anggotanya. Maka hak setiap individu hendaknya dihormati; pendidikan hendaknya membantu peserta didik untuk menjadi merdeka dan independen secara fisik, mental, dan spiritual, pendidikan hendaknya tidak hanya mengembangkan aspek intelektual sebab akan memisahkan dari orang kebanyakan; pendidikan hendaknya memperkaya setiap individu tetapi perbedaan masing-masing pribadi harus tetap dipertimbangkan; pendidikan hendaknya memperkuat rasa percaya diri, setiap orang harus hidup sederhana dan guru hendaknya rela mengorbankan kepentingan-kepentingan dirinya demi kebahagiaan para peserta didiknya. Peserta didik yang dihasilkan adalah peserta didik yang berkepribadian merdeka, sehat fisik, sehat mental, cerdas, menjadi anggota masyarakat yang berguna, mempunyai budi pekerti atau sopan santun yang terpuji, dan bertanggung jawab atas kebahagiaan dirinya dan kesejahteraan orang lain

\section{Pendidikan Sistem Among}

Metode yang sesuai dengan sistem pendidikan ini adalah sistem among yaitu metode pembelajaran dan pendidikan yang berdasarkan pada asih,asah,dan asuh(care and dedivcation based on love). Yang dimaksud manusia mereka adalah seseorang yang mampu berkembang secara utuh dan selaras dari segala aspek kemanusiaannya dan yang mampu menghargai dan menghormati kemanusiaan setiap orang. Oleh karena itu, bagi Ki Hajar Dewantara pepatah ini sangat tepat yaitu educate the head, the hearth, and the hand.
Selain itu, pembelajaran yang diberikan kepada anak didik tidak bersifat paksaan bahkan perilaku memimpin kadang tidak perlu dilakukan. Sebagai gantinya para pendidik harus bersifat ngemong atau among. Para guru tidak seharusnya mengajarkan pengetahuan mengenai dunia secara dogmatik. Sebaliknya, mereka hanya ada dibelakang anak didik sambil memberi dorongan untuk maju, secara halus mengarahkan kejalan yang benar, dan mengawasi kalau-kalau anak didik menghadapi bahaya atau rintangan. Anak didik harus memiliki kebebasan untuk maju menurut karakter masing-masing dan untuk mengasah hati nuraninya.

Ki Hajar Dewwantar beranggapan bahwa pendidikan harus dilakukan melalui tiga lingkungan pendidikan (tripusat pendidikan), yaitu keluarga, sekolah, dan lingkungan sosial (masyarakat). Keluarga merupakan pusat pendidikan pertama dan terpenting, karena sejak timbulnya peradaban manusia sampai sekarang keluarga selalu memiliki pengaruh besar terhadap perkembangan anak. Sekolah sebagai pembantu kelanjutan pendidikan dalam keluarga, sebab pendidikan yang pertama dan utama diperoleh anak di dalam keluarga.

\section{Pandangan Ki Hajar Dewantara tentang Anak}

Ki Hajar Dewantara banyak mempelajari ilmu pendidikan sewaktu beliau diasingkan di Belanda. Frobel dan Montessori merupakan tokoh yang paling sering dijadikan objek belajarnya. Ciri khas dari pendidikan anak menurut $\mathrm{Ki}$ Hajar Dewantara adalah budi pekerti dan sistem among. Khusus PAUD beliau memadukan teori Frobel dan Montessori dan disesuaikan dengan kondisi Indonesia .

\section{Budi Pekerti}

Materi yang paling penting diberikan kepada anak adalah pendidikan budi pekerti. Bentuknya bukan mata pelajaran budi pekerti, tetapi menanamkan 
nilai-nilai, harkat dan martabat kemanusiaan, nilai moral watak, dan pada akhirnya pembentukan manusia yang berkepribadian. Budi pekerti bertujuan untuk mengatur kehidupan manusia.Budi pekerti sama dengan moralitas yang berisi adat istiadat, sopan santun, dan perilaku yang dapat membentuk sikap terhadap manusia, Tuhan,diri sendiri, keluarga, masyarakat, bangsa, dan alam sekitarnya. Jika sikap tersebut sudah bisa ditanamkan ,maka seseorang akan menjadi seorang manusia yang utuh, baik, dan terhormat.

Pendekatan yang baik dan tepat dalam menanamkan nilai budi pekerti pada anak menurut aliran ini adalah dengan memberikan contoh teladan, cerita atau dongeng, dan permainan. Dengan pendekatan tersebut kita dapat mendidik anak tentang budi pekerti, sedang sang anak tidak merasa bahwa sikapnya sedang dibentuk. Kreativitas dan inovasi guru dituntut dalam proses pembelajaran untuk mendidik, khususnya pembentukan sikap melalui pelajaran yang sedang diberikan. Kegiatan ini sesuai dengan program kegiatan pendidikan anak taman kanakkanak yaitu penumbuhan kebiasaankebiasaan bersikap dan berperilaku dengan sopan. Program ini tidak akan berjalan dengan baik jika tidak ada contoh dari orang tua. Oleh karena itu, orang tua perlu diberikan penyuluhan agar bersikap dan berperilaku sopan dihadapan anaknya atau anak diajak berdiskusi tentang sikap dan perilaku anak yang baik.

Ki Hajar Dewantara membagi perkembangan manusia dengan menggunakan interval tujuh tahunan usia kronologi yakni: usia 1-7 tahun dipandang sebagai masa kanak-kanak. Pendidikan yang cocok diberikan pada fase ini yaitu dengan cara pemberian contoh dan pembiasaan. Usia 7-14 tahun dipandang sebagai masa pertumbuhan jiwa dan pikiran. Pendidikan yang cocok pada fase ini yaitu dengan cara pembelajaran, perintah atau hukuman. Usia 14-21 tahun dipandang sebagai masa terbentuknya budi pekerti atau periode sosial. Pendidikan yang cocok pada fase ini yaitu dengan cara mendisiplinkan diri sendiri dan melakukan atau merasakannya secara langsung. Kegiatan menanamkan budi pekerti melalui metode pembiasaan dan pemberian contoh ini juga dapat digunakan untuk mengenalkan dan membelajarkan anak akan prinsip-prinsip, nilai-nilai agama, dan cara beribadah sehari-hari.

\section{Sistem Among}

Inti dari sistem among yang dikemukakan oleh Ki Hajar Dewantara adalah sebagai berikut:

1. Ing Ngarso Sung Tulodo, artinya jika pendidik berada didepan wajib memberikan teladan bagi anak didik. Posisi ini sebaliknya lebih banyak diberikan kepada anak usia dini ,tidak perlu banyak nasihat, petuah dan ceramah.

2. Ing Madya Mangun Karso, artinya jika pendidik berada ditengah-tengah harus lebih banyak membangun atau membangkitkan kemauan sehingga anak mempunyai kesempatan untuk mencoba berbuat sendiri. Anak usia dini sesudah dapat mengerjakan, namun lebih tepat setelah taman kanak-kanak, teladan pendidik sangat diperlukan.

3. Tut Wuri Handayani, artinya jika pendidik dibelakang wajib memberi dorongan dan memantau agar anak mampu bekerja sendiri .

\section{Penerapan dalam Pendidikan}

Ki Hajar Dewantara mengutarakan tentang alat pendidikan yang dapat digunakan dalam mendorong keberhasilan proses pendidikan. Motivasi (dorongan) yang diberikan pada anak baik dari dalam maupun dari luar agar anak memiliki keinginan untuk melakukan kegiatan baik verbal maupun non verbal. Reinforcement (penguatan), memberikan pengulangan kepada anak baik dari dalan diri anak maupun dari luar, agar anak mengetahui dan memahami tentang sesuatu yang diberikan oleh guru dalam proses 
pembelajaran. Reward (penghargaan), ketika anak sudah mampu menyelesaikan tugas lebih dahulu dengan baik, maka pendidik memberikan penghargaan kepada anak dengan memberikan acungan jempol atau memeberikan tanda bintang dan lingkaran penuh. Punishment (sangsi), ketika anak membuang sampah sembarangan, sebagai sangsinya anak disuruh mengambil sampah dan membuangnya ketempat sampah.

Atas keluhuran budi, tugas pendidik yang utama adalah ;

1. Mengembangkan cipta, yaitu mengembangkan kognitif atau daya pikir

2. mengembangkan rasa, yaitu mengembangkan sikap perilaku /afektif

3. mengembangkan karsa, yaitu mengembangkan psikomotorik /keterampilan

Ki Hajar Dewantara menerapkan konsep yang dikemukakanya melalui perguruan yang digagasnya yaitu Taman Siswa. Pendidikan anak penting dilakukan sejak dini. Oleh karena itu, dalam Perguruan Taman Siswa diatur sistem pendidikan ,yaitu jenjang Taman Indria, Taman Muda, Taman Dewasa, Taman Madya dan Taman Sarjana Wiyata, bahkan membuka sekolah yang menyiapkan guru Taman Guru. Pendidikan berisi menanamkan nilai budi pekerti, nilai seni, nilai budaya, kecerdasan, keterampilan, dan agama. Sistem among adalah cara pendekatan atau metode pendidikan yang paling tepat dilakukan di Indonesia, bahkan dikatakan "pendidik adalah hamba anak", ini membuktikan bahwa pendidik harus melayani dan memberi kebebasan pada anak agar senang. Pandangan Ki Hajar Dewantara adalah pembentukan pribadi anak dilakukan oleh dasar (bakat) dan ajar (lingkungan).

Dalam Kamus Besar Bahasa Indonesia, disebutkan bahwa guru adalah orang yang pekerjaannya mengajar. Namun, lebih dari itu Guru tidak hanya seseorang yang bertugas mengajar tetapi juga bertanggung jawab terhadap terhadap perkembangan karakter peserta didik. Guru bertanggung jawab untuk mewariskan sistem nilai kepada peserta didik dan menerjemahkan sistem nilai itu melalui kehidupan pribadinya. Perspektif psikologi pendidikan, mengajar pada prinsipnya berarti proses perbuatan seseorang (guru) yang membuat orang lain(siswa)belajar, dalam arti mengubah seluruh demensi perilakunya. Oleh karena itu, selain mentransfer ilmu dan melatih keterampilan, guru juga diharapkan mampu mendidik anak yang berkarakter ,berbudaya , dan bermoral.

Menurut AL-Ghazali (dalam Barnawi \& M Arifin:92), tugas pendidik yang utama adalah menyempurnakan, membersihkan, menyucikan, serta membawakan hati manusia untuk mendekatkan diri kepada ALLAH Swt. Hatii menjadi objek yang sangat penting dalam soal pendidikan. Hatilah yang akan menentukan sikap seorang individu. Hatii seseorang akan memutuskan apakah ia akan jujur atau berbohong, akan memberi atau meminta, akan bermalas-malasan atau berusaha. Dihatilah tempat diolahnya segala bentuk perasaan dan pikiran untuk menghasilkan suatu sikap.

Jika dilihat dari kedudukannya, guru merupakan makhluk Tuhan, makhluk sosial, dan maklhluk individu. Sebagaii makhluk Tuhan, guru harus memiliki landasan keimanan yang kuat. Landasan keimanan seorang guru menjadi dasar ritual vertikalnya kepada Tuhan Yang Maha Esa. Keimanan yang kuat akan membuat orang menjadi lebih tahan banting dibandingkan dengan orang yang tidak mempunyai landasan keimanan. Sebagaii makhluk sosial, guru memiliki tugas sosial kemasyarakatan. Atas dasar keimanannya, guru harus menyadari dan berusaha sekuat tenaga untuk memenuhi tanggung jawab dirinya sebagai warga negara, anggota keluarga, anggota sekolah dan anggota mayarakat, serta pegawai dalam suatu intansi pendidikan. Sebagai makhluk individu, guru memiliki tanggung jawab untuk meningkatkan kualitas 
hidupnya. Kwalitas diri ditingkatkan melalui pengembangan ilmu yang telah dimilikinya, pangkat dan derajadnya, dan meningkatkan hartanya. Kualitas diri ditingkatkan dengan tetap memperhatikan nilai-nilai ketuhanan dan kemanusiaan. Ketiga aspek kedudukan guru itu melahirkan banyak tugas-tugas hidup yang harus dilaksanakan secara seimbang oleh seorang guru. Keseimbangan yang sinergis dapat membentuk profil guru yang baik dihadapan Tuhan dan manusia melalui peningkatan kualitas diri dari waktu kewaktu.

Pandangan masyarakat jawa, guru memiliki posisi yang sangat terhormat. Istilah guru berasal dari kata digugu lan ditiru. Kata digugu (dipercaya) mengandung maksud bahwa guru mempunyai seperangkat ilmu yang memadai sehingga ia memiliki wawasan dan pandangan yang luas dalam melihat kehidupan. Sedangkan ditiru (diikuti) menyimpan makna bahwa guru merupakan sosok manusia yang memiliki kepribadian yang utuh sehingga tindak tanduknya patut dijadikan panutan oleh peserta didik dan masyarakat.

Tokoh guru yang paling sukses dalam mendidik karakter manusia adalah Nabi Muhammad Saw, beliau merupakan seorang pendidik yang membimbing manusia menuju kemerdekaan dan kebahagiaan yang lebih besar. Kemuliaan sifat yang paling mendasar adalah shiddiq, fathonah, tabligh, dan amanah. Shiddiq artinya jujur, fathonah artinya pandai, tabligh artinya menyampaikan, amanah artinya dapat dipercaya. Keempat karakter esensial inilah yang harus dimiliki oleh setiap individu untuk mengembangkan nilai-nilai mulia lainnya. Dengan demikian, seorang guru harus memiliki sifat-sifat yang lebih spesifik untuk menunjang pekerjaannya dalam mengajar peserta didik. Menurut Firmansyah (dalam Barnawi:94) menyatakan ada delapan sifat keguruan yang telah dicontohkan oleh Nabi Muhammad Saw yang seharusnya kita tiru dan diikuti diantaranya adalah: kasih sayang, sabar, cerdas, tawadhu', bijaksana, pemberi maaf, kepribadian yang kuat, serta yakin terhadap tugas pendidikan.

Kasih sayang .sifat ini wajib dimiliki oleh setiap pendidik sehingga proses pembelajaran yang diberikan menyentuh hingga kerelung kalbu. Implikasinya pendidik menolak untuk tidak suka meringankan beban orang yang dididik.

Sabar, sifat ini adalah bekal yang dibutuhkan untuk menjadi seorang pendidik yang sukses. Keragaman sikap dan kemampuan memahami yang dimiliki oleh anak menjadi tantangan bagi pendidik. Terutama bagi anak yang dikatagorikan lamban dalam memahami materi dibutuhkan kesabarab yang lebih dari pendidik untuk terus mencari cara agar sianak bisa setara pemahamannya dengan yang lain.

Cerdas, seorang pendidik harus mampu menganalisis setiap masalah yang muncul dan memberikan solusi yang tepat untuk mengembangkan kemampuan anak didiknya merupakan wujud dari sifat cerdas. Kecerdasan yang dibituhkan tidak Cuma intelektual, namun juga emosional dan spiritual.

Tawadhu', seorang pendidik sebaiknya memiliki sifat rendah hati.Pantang bagi seorang pendidik memiliki sifat arogan (sombong) meski itu pada anak didiknya. Sifat tawadhu' (rendah hati) kepada siapa saja baik kepada orang tua maupun kepada anak didik sekalipun. Dengan demikian, tidak ada yang renggang antara pendidik dan anak didik, sifat ini akan memudahkan pembelajaran dan akan memperkuat pengaruh baik pendidik kepada anak didik karena penghormatan.

Bijaksana, seorang pendidik tidak boleh mudah terpengaruh dengan kesalahan, bahkan oleh keburukan yang dihadapinya dengan bijaksana dan lapang dada sehingga akan mempermudah baginya memecahkan sebab-sebab permasalahan tersebut.

Pemberi maaf, pendidik dituntut untuk mudah memberikan maaf meskipun 
ada sanksi yang diberikan kepada anak didik yang menjadi pelaku kesalahan sebagai bagian dari edukasi.

Kepribadian yang kuat, sanksi bisa jadi tidak diperlukan dalam mengedukasi anak didik jika seorang pendidik memiliki kepribadian yang kuat (kewibawaan, tidak cacat moral, dan tidak diragukan kemampuannya). Sehingga memunculkan apresiasi dari anak didik, bukannya apriori. Secara otomatis, kepribadian yang kuat bisa mencegah terjadinya banyak kesalahan dan mampu menanamkan keyakinan dalam diri anak.

\section{Yakin terhadap tugas}

pendidikan, pendidik hendaklah selalu optimis dan penuh keyakinan terhadap tugas yang diembannya.

Menurut AL-Ghazali (dalam Barnawi:96), seseorang yang memiliki akal sempurna dan akhlak yang terpuji baru boleh menjadi guru. Tidak hanya itu, ada sifat-sifat khusus yang harus dimiliki guru sebagai berikut :

1. Rasa Kasih Sayang dan Simpatik, AlGozali memberi nasehat pada guru untuk berlaku sebagai seorang ayah terhadap anaknya, bahkan ia berpendapat bahwa hak seorang guru itu lebih besar ketimbang seorang ayah terhadap anaknya.

2. Tulus Ikhlas, guru tidak layak menuntut honorarium sebagai jasa tugas mengajar dan tidak patut menungu-nunggu pujian, ucapan terimakasih, atau balas jasa dari muridnya.

3. Jujur dan terpercaya, seorang guru sebaiknya menjadi seorang penunjuk tepercaya dan jujur terhadapnmuridnya. Sebagai penunjuk (penasehat) yang tepercaya, guru tidak membiarkan muridnya memulai pelajaran yang tinggi sebelum menyelesaikan pelajaran sebelumnya. Ia selalu mengingatkan pada muridnya bahwa tujuan akhir belajar ialah bukan bermegah diri atau mengejar pangkat atau kedudukan.
4. Lemah lembut dalam memberi nasehat, guru hendaklah tidak berlaku kasar terhadap murid dalam mendidik tingkah laku.

5. Lapang dada, seorang guru tidak pantas mencela ilmu-ilmu yang berada diluar tanggung jawabnya dihadapan murid-muridnya.

6. Memperlihatkan perbedaan individu, guru tidak boleh memberi pelajaran yang tidak mampu dicapai oleh kemampuan akalnya, yang menyebabkan ia menjahuinya dan memerosotkan daya pikirnya.

7. Mengajar tuntas (tidak pelit terhadap ilmu), hendaknya seorang guru menyampaikan kepada miridnya yang kurang cerdas ilmu pengetahuan secara jelas dan tuntas sesuai dengan umur muridnya,

8. Memiliki idealisme.

\section{Daftar Pustaka}

Kesuma, Dharma,dkk.(2011). Pendidikan Karakter:Kajian Teori dan Praktik di Sekolah. Bandung: Rosda Karya .

Kunandar. (2011). Guru Profesional Implementasi Kurikulum Tingkat Satuan Pendidikan (KTSP) dan Sukses dan Sertifikasi Guru. Jakarta: Raja Grafindo Persada.

Masjid, Abdul \& Andayani, Dian. (2011). Pendidikan Karakter Perspektif Islam. Bandung: Rosda.

Mu'in F. (2011). Pendidikan Karakter : Konstruksi Teoritik \& Praktik . Yogyakarta: Ar-Ruz Media .

Munir, Abdullah. (2000). Pendidikan Karakter: Membangun Karakter Anak Sejak dari Rumah. Yogyakarta: Pedagogia

Naim, Ngainu. (2009). Menjadi Guru Inspiratif. Yogyakarta: Pustaka Pelajar.

Tim Penyusun .tt.Peraturan Menteri Pendidikan Nasional Republik Indonesia nomor 41 tahun 2007 
tentang Standar Proses .Jakarta

:BSNP

Zubaidi . (2011). Desain Pendidikan

Karakter: Konsepsi dan

Aplikasinya dalam Lemabaga

Pendididkan. Jakarta: Kencana .

Suyatno. (2010). "Peran Pendidikan

sebagai Modal Utama Membangun

Karakter Bangsa". Makalah

disampaikan dalam Sarasehan

Nasional Pengembangan

Pendidikan Budaya Dan Karakter

Bangsa oleh Kopertis Wilayah 3

DKI Jakarta ,12 januari 2010.

Sumber laman

Putri Pandan Wangi. (2005). Mendidik

Anak Prasekolah .Yogyakarta:

Damar Pustaka

Darmiyati zuchdi .(2009).Pendidikan

Karakter. Yogyakarta :UNY Press

http://www.kopertis8.org/.../pendidikan

$\% 20$ Karakter

http://www.slideshare.net/gusipung/pendidi kan-karakter

http://aadesanjaya.blogspot.com/2011/07/s

ilabus-dan-rpp-bahasa-

inggris_31.html 